\title{
In situ and experimental evidence for effects of elevated pH on protistan and metazoan grazers
}

Hansen, Benni W.; Andersen, Christian M.B.; Hansen, Per J.; Nielsen, Torkel Gissel; Vismann, Bent; Tiselius, Peter

Published in:

Journal of Plankton Research

Link to article, DOI:

10.1093/plankt/fbz020

Publication date:

2019

Document Version

Publisher's PDF, also known as Version of record

Link back to DTU Orbit

Citation (APA):

Hansen, B. W., Andersen, C. M. B., Hansen, P. J., Nielsen, T. G., Vismann, B., \& Tiselius, P. (2019). In situ and experimental evidence for effects of elevated $\mathrm{pH}$ on protistan and metazoan grazers. Journal of Plankton Research, 41(3), 257-271. https://doi.org/10.1093/plankt/fbz020

\section{General rights}

Copyright and moral rights for the publications made accessible in the public portal are retained by the authors and/or other copyright owners and it is a condition of accessing publications that users recognise and abide by the legal requirements associated with these rights.

- Users may download and print one copy of any publication from the public portal for the purpose of private study or research.

- You may not further distribute the material or use it for any profit-making activity or commercial gain

- You may freely distribute the URL identifying the publication in the public portal 


\title{
ORIGINAL ARTICLE
}

\section{In situ and experimental evidence for effects of elevated $\mathrm{pH}$ on protistan and metazoan grazers}

\begin{abstract}
BENNI W. HANSEN ${ }^{1}{ }^{1}$, GHRISTIAN M. B. ANDERSEN ${ }^{2,3}$, PER J. HANSEN ${ }^{4}$, TORKEL G. NIELSEN ${ }^{(D)}{ }^{5}$, BENT VISMANN ${ }^{4}$ AND PETER TISELIUS ${ }^{6}$

${ }^{1}$ DEPARTMENT OF SGIENCE AND ENVIRONMENT, ROSKILDE UNIVERSITY, UNIVERSITETSVEJ I BUILDING II.2, DK-4OOO ROSKILDE, DENMARK, ${ }^{2}$ FACULTY OF SCIENCE, DEPARTMENT OF ECOLOGY, ENVIRONMENT AND PLANT SCIENCES, STOCKHOLM UNIVERSITY RINGVEJ 32 , SE-IO6 9I STOCKHOLM, SWEDEN ${ }^{3}$ PRESENT ADDRESS: THISTED GYMNASIUM, STRANDPROMENADEN 5, DK-77OO THISTED, DENMARK ${ }^{4}$ MARINE BIOLOGICAL SECTION, UNIVERSITY OF COPENHAGEN, KEMITORVET BUILDING 202, DK-3OOO HELSINGøR, DENMARK ${ }^{5}$ TEGHNICAL UNIVERSITY OF DENMARK, NATIONAL INSTITUTE OF AQUATIC RESSOURCES, DK-2800 LYNGBY, DENMARK ${ }^{6}$ DEPARTMENT OF BIOLOGICAL AND ENVIRONMENTAL SGIENCES - KRISTINEBERG, UNIVERSITY OF GOTHENBURG, THE SVEN LOVÉN CENTRE FOR MARINE SCIENCES, KRISTINEBERG 566, SE 450 34, FISKEBÄGKSKIL, SWEDEN
\end{abstract}

*CORRESPONDING AUTHOR: bhansen@ruc.dk

Received January 30, 2019; editorial decision April 11, 2019; accepted April 12, 2019

Corresponding editor: John Dolan

Plankton succession was studied in a hyper-eutrophic stratified estuary, Mariager Fjord, Denmark. Above the pycnocline $(15 \mathrm{~m}) \mathrm{pH}$ increased from 8.5 to 9.2 and the oxygen increased to super saturation after $5 \mathrm{~d}$ of sunny weather due to high primary production. The protistan grazers were dominated by heterotrophic dinoflagellates and mixotrophic and heterotrophic ciliates. Metazooplankton was dominated by meroplankton, rotifers and the copepod, Acartia tonsa, all with a relatively low biomass. Cirriped nauplii occupied the upper strata while polychaete larvae populated the whole water column. Bivalve larvae occurred occasionally above the pycnocline even at very high $\mathrm{pH}$. In $\mathrm{pH}$ challenge experiments, the mixotrophic ciliate Mesodinium rubrum was the least $\mathrm{pH}$ tolerant species, followed by Strombidium spp., which did not cope well with seawater $\mathrm{pH}>8.5$. Some heterotrophic dinoflagellates were more tolerant with net growth at $\mathrm{pH}>9$. The predominant rotifer Synchaeta sp. tolerated up to $\mathrm{pH} 9.5$ and the copepod survived $\mathrm{pH} 10$ but stopped producing eggs at $\mathrm{pH} 9.5$ with unaffected egg hatching success. The polychaete and cirriped larvae tolerated $\mathrm{pH}$ 9.5, but bivalve larvae showed decreased survival already at $\mathrm{pH}$ 8.5. In situ distribution patterns and $\mathrm{pH}$ challenge experiments suggest that $\mathrm{pH}$ indeed contribute to structuring zooplankton distribution.

KEYWORDS: Mariager Fjord; eutrophication; structuring factor; zooplankton; incubation experiments 


\section{INTRODUGTION}

Mariager Fjord is $35 \mathrm{~km}$ long, with a maximum depth of $30 \mathrm{~m}$ and a sill at its mouth. Located at 56 39.08 , $\mathrm{N}, 9^{\circ} 58.50^{\prime} \mathrm{E}$, it is a hypereutrophic estuary. Its inner basin has a permanent halocline at $10-15 \mathrm{~m}$ overlying hypoxic water. The estuary is characterized by elevated $\mathrm{pH}$ of up to 9.75 in the photic zone during the high productive summer period (Hansen et al., 2002; Tiselius et al., 2008). This potentially may affect the productivity of the system as well as cause a reduction in species diversity.

It has been suggested that at high $\mathrm{pH}$ levels the availability of inorganic carbon in a form that phytoplankton can utilize $\left(\mathrm{CO}_{2}\right.$ and $\left.\mathrm{HCO}^{-}\right)$may become limiting to both freshwater and marine phytoplankton growth and photosynthesis (Talling, 1976; Chen and Durbin, 1994; Hinga, 2002; Hansen et al., 2007). In addition, the elevated $\mathrm{pH}$ itself may affect the growth of the algae probably due to inability to maintain a constant $\mathrm{pH}$ cell environment, which may be crucial for enzymatic processes inside the cells (e.g. Hansen et al., 2007).

The current information of how heterotrophic organisms respond to high $\mathrm{pH}$ is very sparse. Droop (1959) found that the heterotrophic dinoflagellate Oxyrrhis marina is highly pH-tolerant and could grow well at pH 10 . Pedersen and Hansen (2003b) studied the effect of high $\mathrm{pH}$ on four ciliates and two heterotrophic dinoflagellates in laboratory cultures, and found that some species are highly $\mathrm{pH}$-tolerant and grew well at $\mathrm{pH}$ 9.5-10, while others were quite sensitive to elevated $\mathrm{pH}$. Their growth was affected above $\mathrm{pH} 8.5$ and they could not survive at $\mathrm{pH}$ exceeding 8.9. The tolerance among copepods also differ. Species with an oceanic-neritic distribution like Oithona similis had a $\mathrm{LC}_{50}$ at $\mathrm{pH}$ 8.4, while some estuarine species like Eurytemora affinis were much more tolerant and did not exhibit $\mathrm{LC}_{50}$ before $\mathrm{pH}$ reached 9.5 (Hansen et al., 2017). Ringwood and Keppler (2002) even report a stimulated growth response in juvenile clams, Mercenaria mercenaria at slightly elevated $\mathrm{pH}$. The exact reasons for the differences in tolerances to elevated $\mathrm{pH}$ are however still unknown. Ringwood and Keppler (2002) stated 'It is time to reconsider the potential role of $\mathrm{pH}$ in estuaries - it may be more important than previously appreciated'.

The pelagic environment in Mariager Fjord seems quite hostile at times. During summer, the estuary is characterized by high primary production mainly by chain-forming diatoms, and the heterotrophic protistan and metazoan plankton benefit from the surplus food always above saturation levels. However, taxa that cannot feed on large chain-forming diatoms (e.g. ciliary feeders like bivalve larvae and ciliates) suffer from food limitation (e.g. Petersen et al., 2002). In late summer, the zooplank- ton community additionally experiences deteriorating environmental conditions including anoxia and sulfide (Fenchel et al., 1995). Due to frequent severe hypoxic and even anoxic events, the inner section of Mariager Fjord is susceptible to recurring defaunation (Hansen et al., 2002) followed by recolonization by propagules brought in by water intrusions from source populations in the outer estuary and open waters in Kattegat. The metazoan plankton is characterized by a low diversity, with essentially only one opportunistic copepod species (Acartia tonsa) showing low biomass despite high reproduction (Tiselius et al., 2008). The protistan grazers, with short generation times, are dominated by a few completely heterotrophic species. The meroplankton are composed of several taxa (Hansen et al., 2002; Petersen et al., 2002), supplied by local populations and by the import from open water habitats. Predation pressure from pelagic zooplanktivores (fish and jellyfish) is modest and so is diurnal vertical migration due to anoxia below the pycnocline. More specifically, we expected that oxygen availability and in particular $\mathrm{pH}$, determined the structure and distribution of the plankton community. To test this hypothesis we monitored environmental parameters and plankton in time and space over 9 days during late August 2005. Moreover, we conducted short-term challenge experiments on zooplankton $\mathrm{pH}$ tolerance. Our experimental variables were survival, and in addition for the protistan grazers and rotifers, their population growth, and for the copepods, egg production and egg hatching success. We aimed to resolve the spatial and temporal zooplankton distribution in the estuary, with special focus upon $\mathrm{pH}$. This was achieved by linking in situ observations with obtained $\mathrm{pH}$ tolerance results.

\section{METHOD}

\section{In situ sampling program}

Samples were taken around true noon on 16, 18, 20, 22 and 24 August 2005 at a station in the deepest, central part of Mariager Fjord (Fig. 1). Water column structure was identified by Conductivity, Temperature, Density (CTD) casts (ME-profiler, Meerestechnik) measuring temperature, salinity and fluorescence as a proxy for chlorophyll $a$. Aliquots of $3 \times 0.5 \mathrm{~L}$ were sampled every second meter through the water column and filtered onto 25 mm GFC-filters. The filters were extracted in $5 \mathrm{~mL} \mathrm{96 \%}$ ethanol overnight (Jespersen and Christoffersen, 1987), and pigments were measured on a Chl $a$ TD-700 fluorometer (Turner) calibrated against a chl $a$ standard before and after acidification (Yentsch and Menzel, 1963). Oxygen concentration profiles were from the surface down to 
$10 \mathrm{~m}$ of water depth measured using an oxygen meter (WTW oxi 196) equipped with a probe (WTW 19610) inserted into a stirrer unit (WTW BR190). At water depths of 11-20 m, samples were taken every second meter from $10 \mathrm{~L}$ Niskin sampling bottles and oxygen concentrations were measured with spectrophotometric Winkler determination as described by Labasque et al. (2004). Based on the water column structure, zooplankton sampling depths were identified and collected using a 30L Niskin sampling bottle at discrete depths $(0,2,4,6,8$, $10,12,15$ and $20 \mathrm{~m}$ ). The water samples were decanted to $100 \mathrm{~mL}$ brown medicine bottles and fixed with acid Lugol solution (1\% final concentration) for enumeration of ciliates and heterotrophic dinoflagellates, and the rest of the whole $30 \mathrm{~L}$ sample was buffered formalin concentrated on a $45 \mu \mathrm{m}$ mesh size sieve and fixed in formaldehyde (5\% final concentration) for enumeration of meroplankton and copepods. For protistan grazers and rotifers, up to 10 aliquots of $10 \mathrm{~mL}$ were analysed under inverted microscope (×400 magnification, Üthermöhl 1958). The heterotrophic protists were so characteristic that they were easily recognizable in Lugol fixated samples. For meroplankton, all samples were analyzed under a dissection microscope ( $\times 50$ magnification) and all organisms were counted and determined to major taxa at the level of Class. All zooplankton abundance data no matter numerical levels are presented. In the case of relatively low counting numbers, we are aware that these are imprecisely determined; however, data indicate low abundance at the location. Copepods were determined to species (see Tiselius et al., 2008). Depth-integrated zooplankton biomasses $\left(\mathrm{g} \mathrm{C} \mathrm{m}^{-2}\right.$ ) were calculated by trapezoidal integrations, based on abundance and length measurements of the organisms. To obtain biomass the protistan cell volumes were calculated separately for each species/size group on the basis of linear dimensions, assuming simple geometrical shapes. Cell carbon was estimated

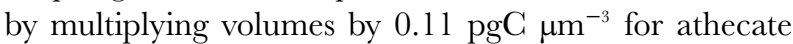

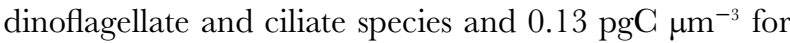
thecate dinoflagellate species (Edler, 1979; Lessard, 1991). The carbon conversion of multicellular zooplankton was made using literature regressions; $A$. tonsa (Berggreen et al., 1988), planula larvae (as naked ciliates), gastropod larvae (Hansen and Ockelmann, 1991), bivalve larvae (Fotel et al., 1999), polychaeta larvae (Hansen, 1999), cirriped nauplii (as A. tonsa nauplii sensu Berggreen et al., 1988) and rotifers (Hansen et al., 1997). To verify the diurnal pH shift in the upper $20 \mathrm{~m}$, we conducted two diurnal studies (20-21 and 24-25 August). The oxygen (same oxygen meter as above) and the $\mathrm{pH}$ was measured directly in the Niskin sampling bottle on each sampling occasion using a Sentron ${ }^{\circledR}$ Argus pH meter equipped with a HOT-Fet line $\mathrm{pH}$ probe calibrated using standard buffers of $\mathrm{pH}$
7 and 10 at all sampling depths every fourth hour from 10-10 a.m.

\section{pH challenge experiments conducted in microosms and bottles}

$\mathrm{pH}$ in seawater can in principle be changed in different ways. The most common methods are (i) by bubbling with gasses, i.e $\mathrm{CO}_{2}$ for lowering the $\mathrm{pH}$ and free $\mathrm{N}$ to wash out the inorganic carbon pool to create elevated $\mathrm{pH}$ or (ii) the addition of an acid ( $\mathrm{HCl}$ ) or a base (often $\mathrm{NaOH}$ ). Each method has its strengths and weaknesses. The bubbling with gasses mimics the removal of inorganic carbon in a similar way as the algae does. However, bubbling natural communities will strongly affect especially the protist community, since they are very sensitive to turbulence and air bubbles (e.g. Rost et al., 2008). Addition of a base allows for changes in seawater $\mathrm{pH}$ without, in principle any effect on the composition of the plankton community. This method has been applied with success in cases where large differences in seawater $\mathrm{pH}$ are required for experimental purposes (e.g. Pedersen and Hansen, 2003a; Berge et al., 2010; Nielsen et al., 2010). The downside of this method is that the pool of inorganic carbon stays more or less constant because it is not removed from the water, thus potentially underestimating the effects of elevated $\mathrm{pH}$ on photosynthetic protists. The focus in the present contribution is mainly on the heterotrophic organisms that are not expected to be affected by the inorganic carbon pool in the water, but rather $\mathrm{pH}$ itself. Therefore, we chose the method with base adjustments. We only observed minor diurnal changes in $\mathrm{pH}$ in the challenge experiments $(<0.1 \mathrm{pH}$ unit each time).

The $\mathrm{pH}$ challenge experiments were conducted for monitoring the effect on survival and growth of various zooplankton taxa. In situ microcosms (30 L polycarbonate bottles) for protistan grazers and rotifers, and bottles (50 mL NUNC plastic bottles) for meroplankton and 500 $\mathrm{ml}$ polycarbonate bottles for copepods were used, respectively. For the $30 \mathrm{~L}$ bottles, water from $2 \mathrm{~m}$ was collected on 18th August. In brief, the $\mathrm{pH}$ in each microcosm was measured and adjusted by adding $0.1 \mathrm{~N} \mathrm{NaOH}$ or $\mathrm{HCl}$ to $\mathrm{pH}$ of 8.0, 8.5, 9.0, 9.5 and likewise in the bottle experiments that also contained $\mathrm{pH} 10$ and 10.5. The collected water had an initial $\mathrm{pH}$ of 8.65 . The adjustments for the 8.0 and 8.5 experiments were done instantaneously. For the 9.0 treatment, they were first subjected to 8.5 for 6 $\mathrm{h}$ where after $\mathrm{pH}$ was raised and for the 9.5 treatments they were adjusted from 9.0 to 9.5 after another 6 hours and so forth for the 10 and 10.5 treatments. The $\mathrm{pH}$ was measured directly in the microcosms using a Sentron ${ }^{\circledR}$ Argus $\mathrm{pH}$ meter equipped with a HOT-Fet line $\mathrm{pH}$ probe calibrated using standard buffers of $\mathrm{pH} 7$ and 10 . 


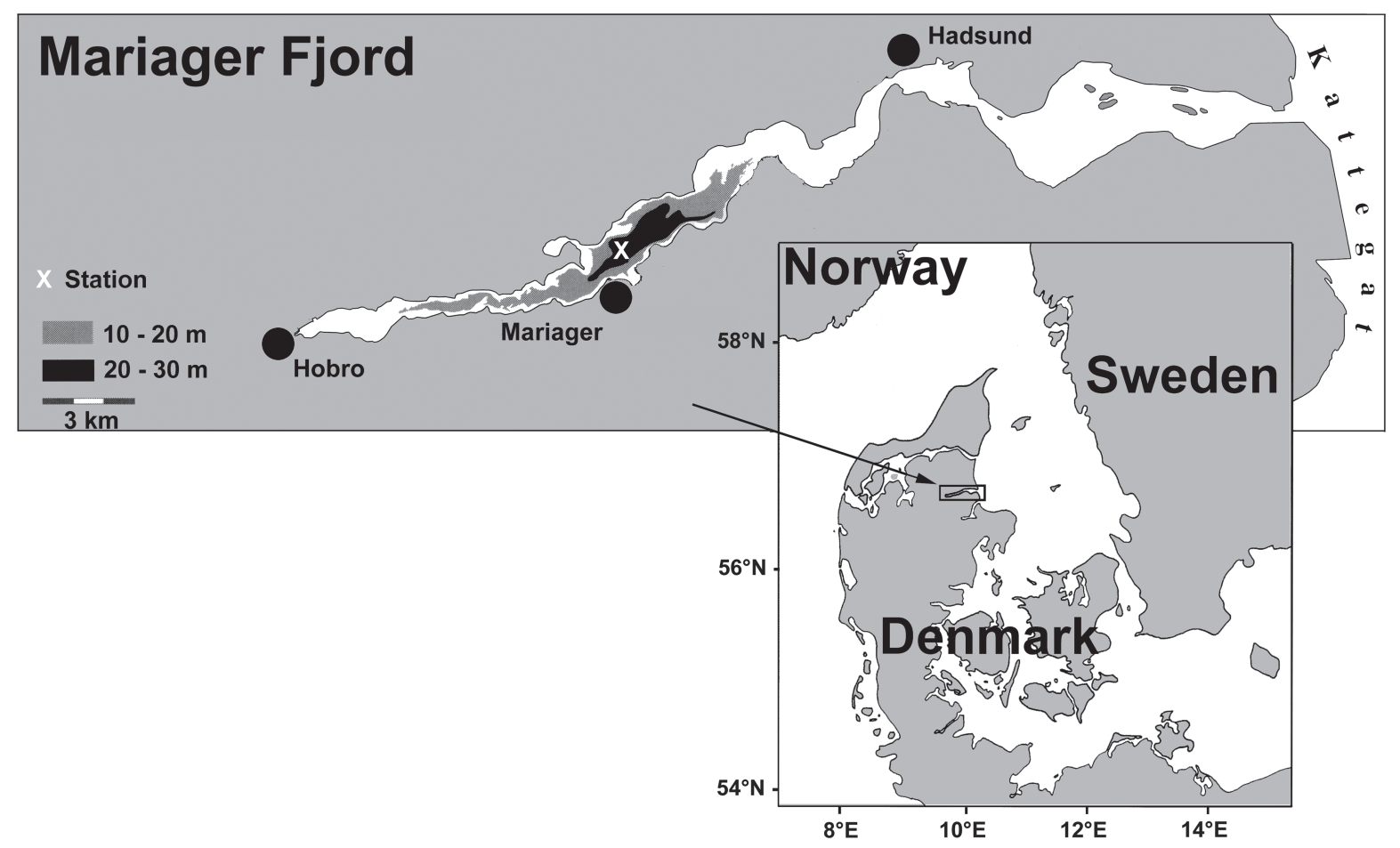

Fig. 1. Map of Mariager Fjord on the east coast of Jutland, Denmark. Sampling station is indicated by X (position: $56^{\circ} 39.08^{\prime} \mathrm{N}, 9^{\circ} 58.50^{\prime} \mathrm{E}$ ). The area considered in the present paper is the inner part of the estuary sampled through a $9 \mathrm{~d}$ campaign in August 2005.

Microcosmos incubations in the estuary

Twelve microcosms were filled with $200-\mu \mathrm{m}$ pre-screened estuary water from $2 \mathrm{~m}$ depth. Three replicates of each $\mathrm{pH}$ treatment were adjusted to $\mathrm{pH} 8,8.5,9$ and 9.5 initially as stated above as well as once every day the following days. The microcosms were incubated for $72 \mathrm{~h}$ (18-21 August) floating at the surface of the estuary. Initial and final samples $(50 \mathrm{~mL})$ were taken and zooplankton fixated with acid Lugol solution (1\% final concentration) and analyzed by inverted microscopy.

\section{Bottle incubations in the laboratory}

The experiments were conducted in a temperature controlled walk-in container set to in situ estuary surface water temperature $\left(17-20^{\circ} \mathrm{C}\right.$ ) and dim light. The $\mathrm{pH}$ range was from 8.0 to 10.5 in steps of 0.5 units. For all incubations, the $\mathrm{pH}$ was adjusted stepwise as described above for the microcosm experiments. Meroplankton experiments were done in 70- $\mu \mathrm{m}$ pre-screened estuary water in triplicate and three control bottles were not manipulated. For the bivalve larvae only one start bottle and one final bottle per treatment were used as too few larvae were available. Larvae were individually picked with 25 bivalve larvae (Mytilus edulis, D-stage velichoncha larvae originating from Limfjord situated north of Mariager Fjord), 50 polychaete larvae (dominated by spionid larvae of variable sizes) and 50 cirriped nauplii (Balanus sp.) both collected from Mariager Fjord was added to each incubation bottle. We inspected the animals directly in the incubation bottles under a dissecting microscope after acclimation to $\mathrm{pH}$ 's and observed that all were alive when the 24-h challenge experiments were initiated.

In the challenge experiments testing effects of $\mathrm{pH}$ on the copepod $A$. tonsa on survival, egg production and egg hatching, specimens (females) were collected by $200 \mu \mathrm{m}$ mesh size closed cod-end WP-2 net hauls. The catch from the hauls were gently brought to the temperature controlled laboratory container in an insulated box. Thereafter individuals were individually pipetted under a dissecting microscope, and transferred to 2 -L polycarbonate bottles (20 per bottle) containing 45 $\mu \mathrm{m}$ filtered estuary water. The $\mathrm{pH}$ was adjusted gradually, every $6 \mathrm{~h}$ in triplicate as above, 8.0, 8.5, 9.0, 9.5, 10.0 and 10.5. After acclimation, the copepods $(n=20)$ were picked individually and transferred to three replicate $500 \mathrm{~mL}$ polycarbonate bottles and incubated for $24 \mathrm{~h}$ at their respective $\mathrm{pH}$ treatment. The protocol for death determination was to poke the copepods with a dissecting 
needle after leaving them in a Petri dish for 3 minutes. If no movement at all, the copepod was considered dead.

From the same incubation bottles, eggs were separated from copepods, by sequential filtration $(200 \mu \mathrm{m}$ followed by $45 \mu \mathrm{m}$ ), transferred to Petri dishes with $10 \mathrm{~mL}$ water from the respective bottles, and counted (egg production). Afterwards the eggs were incubated for $24 \mathrm{~h}$ in Petri dishes using the same media as for the survival experiment. After incubation, the hatching success was determined by counting the eggs and live and dead nauplii under a dissecting microscope.

\section{Statistical methods}

The effect of elevated $\mathrm{pH}$ on survival and growth, egg production, hatching rates in the challenge experiments was evaluated using one-factor ANOVA with $\mathrm{pH}$ levels as fixed factors. The following three comparisons were made: (i) survival of animals, (ii) egg production and hatching success for $A$. tonsa and (iii) microcosm experiments over 3 days in which abundances in exposed communities of plankton were recorded. For survival of meroplankton, copepods and organisms in the bottle incubations, the number of living animals at the end of the incubations at $\mathrm{pH}=8$ was used as a common control for increased $\mathrm{pH}$ levels. Differences between the initial abundances and those after $72 \mathrm{~h}$ at $\mathrm{pH} 8$ were tested with $t$-tests. Egg production and hatching success at elevated $\mathrm{pH}$ levels were compared to rates at $\mathrm{pH}=8$ that served as the common control. For both microcosm and bottle experiments, the effect of elevated $\mathrm{pH}$ levels were compared to the respective controls ( $\mathrm{pH}$ 8) using ANOVA and Dunnett's post-hoc test (two-sided). Significant differences were assigned when $P \leq 0.05$ indicated in figures by an asterisk $(*)$. Number of replicates were too few $(n=3)$ to conduct rigorous tests for normality, and the requirement of equal variances for all treatments were judged from box-plots rather than from formal tests. Indeed, variances differed significantly in some survival experiments (Lohmaniella oviformis, polychaete larvae and A. tonsa), but in all cases the means were also very different. All statistical tests were performed using IBM SPSS Statistics (v. 25).

\section{RESULTS}

\section{In situ observations}

Mariager Fjord zooplankton assemblage was mainly characterized by protozoan grazers and meroplankton. The meroplankton accounted four major groups,
Gastropoda-, Bivalvia-, Polychaeta- and Cirripedia larvae (Fig. 2). The inner estuary was strongly stratified during the campaign, with a warm $\left(17\right.$ to $\left.20^{\circ} \mathrm{C}\right)$; mixed surface layer down to $12-15 \mathrm{~m}$ and cold $\left(<5^{\circ} \mathrm{C}\right)$, deep waters below $20 \mathrm{~m}$ (Fig. 3). Salinity profiles were stable throughout the campaign and ranged from 15 to 16 in the upper mixed layer, to 20 in the deep water. The strong thermocline was located at $15 \mathrm{~m}$ and coincided with the weaker halocline together forming a pycnocline at $\sim 15$ $\mathrm{m}$ of depth. Fig. 4 depict that oxygen was present above $15 \mathrm{~m}$, but declined rapidly below the pycnocline. The condition reached anoxia at $20 \mathrm{~m}$ and below (data not shown). Based on the smell from the water samples we observed that sulfide was present at $20 \mathrm{~m}$ and episodically occurred at $15 \mathrm{~m}$. $\mathrm{pH}$ was $\sim 8$ at the pycnocline dropping to $\mathrm{pH} 7.5$ close to the bottom. $\mathrm{pH}$ increased from 8.5 on 17th August to $\mathrm{pH} 9.2$ on 22 August in the upper water column, where after it decreased slightly toward the end of the investigation (Fig. 4). Oxygen concentration below the pycnocline demonstrated anoxia. Just above the pycnocline it was touching severe hypoxia $(2 \mathrm{mg}$ $\mathrm{L}^{-1}$ ) during afternoon and increased with time to reach hypoxia (4 $\mathrm{mg} \mathrm{L}^{-1}$ ) during evening (Fig. 5). Further up in the water column oxygen fluctuated diurnally always above adequate concentration for zooplankton and it build up to supersaturated level $>10$ reaching $16 \mathrm{mg} \mathrm{L}^{-1}$ during afternoon. However, $\mathrm{pH}$ were more constant diurnally with only minor drops in $\mathrm{pH}$ during nighttime (which is only $6 \mathrm{~h}$ at this time of the year). The $\mathrm{pH}$ in $0 \mathrm{~m}$ depth ranged from 8.92 to 9.13 , in 10 $\mathrm{m}$ depth from 8.32 to 8.50 and in $20 \mathrm{~m}$ depth, it was constant 7.8 throughout $24 \mathrm{~h}$ (Fig. 5). There were no major exchanges of water with the Kattegat judged from the CTD profiles that showed a stable stratified water column.

During the campaign, a bloom of the chain-forming diatom Skeletonema marinoi resulted in increasing chlorophyll a concentrations. From already high values (15-18 $\left.\mu \mathrm{g} \mathrm{chl} a \mathrm{~L}^{-1}\right)$ on the first date, the bloom more than doubled in biomass in $2 \mathrm{~d}$, reaching peak values of $46 \mu \mathrm{g} \mathrm{chl} a \mathrm{~L}^{-1}$ on 18 August (Fig. 4). Within 6 days, the bloom disappeared, chl $a$ concentrations went back to the original values, but the phytoplankton biomass was now mainly dominated by the phototrophic dinoflagellate Heterocapsa triquetra instead of S. marinoi.

Protistan grazers were dominated by heterotrophic and mixotrophic ciliates (L. oviformis, and especially Strombidium spp. and Mesodinium rubrum) consistently found above the pycnocline and by heterotrophic dinoflagellates, Gymnodinium dominans and Oblea rotunda, suspended in the entire water column. We depict the distribution patterns of the most dominant groups of protistan grazers in Fig. 6 . In the upper $10 \mathrm{~m}$ metazoan holoplanktonic grazers 


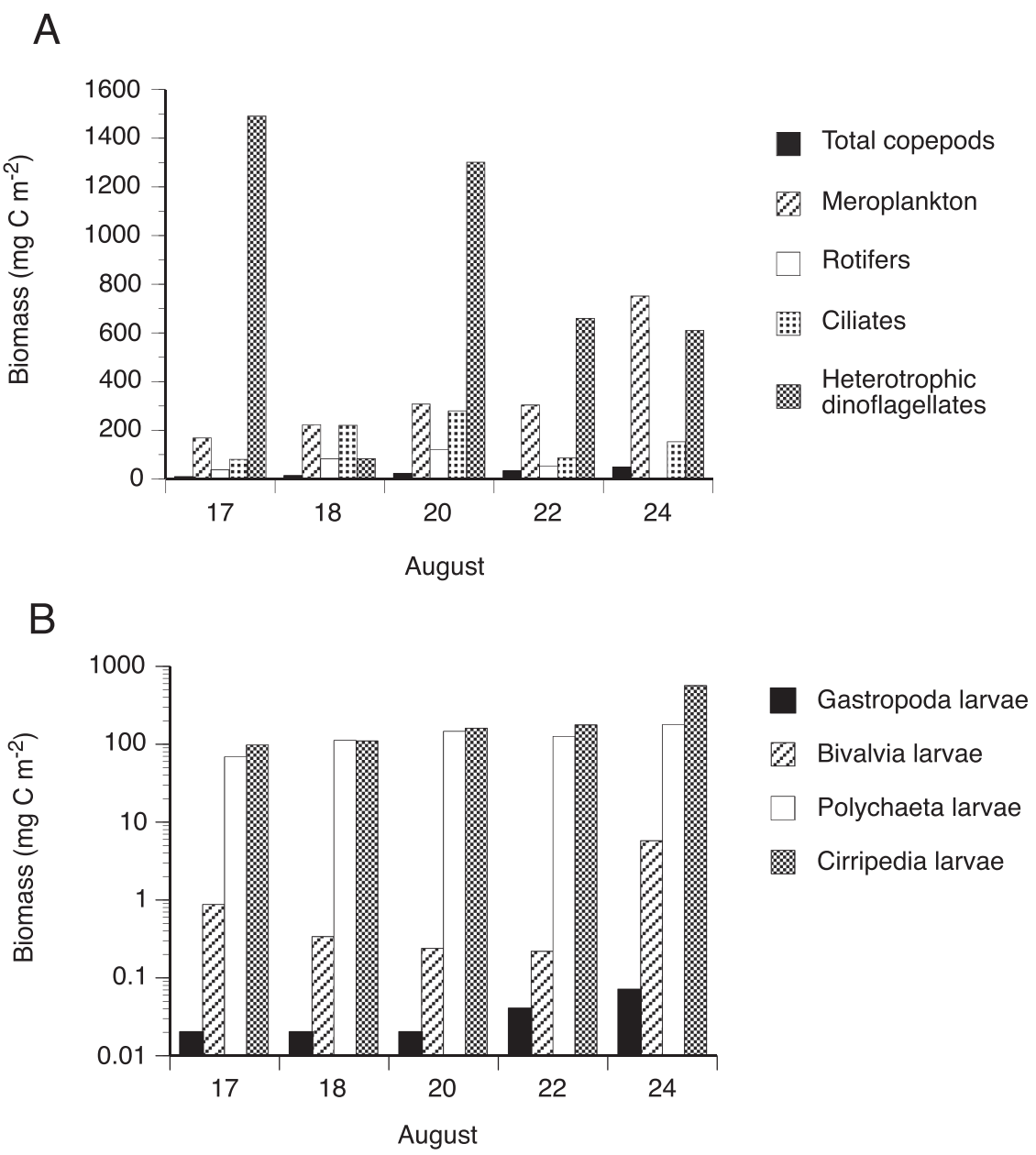

Fig. 2. Depth integrated biomass estimated from size of $\mathbf{A}$ : main holozooplankton taxa and $\mathbf{B}$ : main meroplankton groups present in the inner part of Mariager Fjord. Note log scale in B.

were dominated by rotifers Synchaeta and Trichocercidae species and others (Fig. 7). The meroplankton exhibited somewhat different distribution among taxa in both time and space (Fig. 7). The ciliated planula larvae were present first half of the campaign and situated from 15 to $5 \mathrm{~m}$ depth. Other ciliated larvae were represented by (i) gastropoda larvae, present all through the campaign in $10-5 \mathrm{~m}$ depth; (ii) bivalvia larvae, present in the upper $10 \mathrm{~m}$ just at the beginning and the very end of the campaign; and (iii) polychaeta larvae (mainly spionid metatrochophorans of variable sizes), with the most abundant presence all through the water column, but mostly in the upper $7 \mathrm{~m}$. The predominant cirriped nauplii larvae, Balanus sp., were most frequent the first half of the campaign in the upper 7-8 $\mathrm{m}$ of the water column.

Among larger mesozooplankton, the copepod $A$. tonsa was the dominant species (see Tiselius et al., 2008 for details). Only a few Centropages spp., E. affinis, Oithona spp. and harpacticoids were recorded, and together they constituted $<5 \%$ of the copepod abundance.

\section{pH challenge experiments}

Microcosm experiment

The microcosm experiment investigated potential effects of Mariager Fjord relevant elevated $\mathrm{pH}$ on protistan grazers and the rotifers (Fig. 8). After 3 days of incubation the $\mathrm{pH} 8$ treatment was significantly different from the start concentration. The mixotrophic ciliate $M$. rubrum had declined significantly in number from the start $(t-$ test, $P=0.043$ ). Nevertheless, this species was found in the $\mathrm{pH} 8$ and 8.5 treatments after 3 days of incubation, while it had disappeared completely from the $\mathrm{pH}$ treatments 9 and above. The other protistan grazers and 


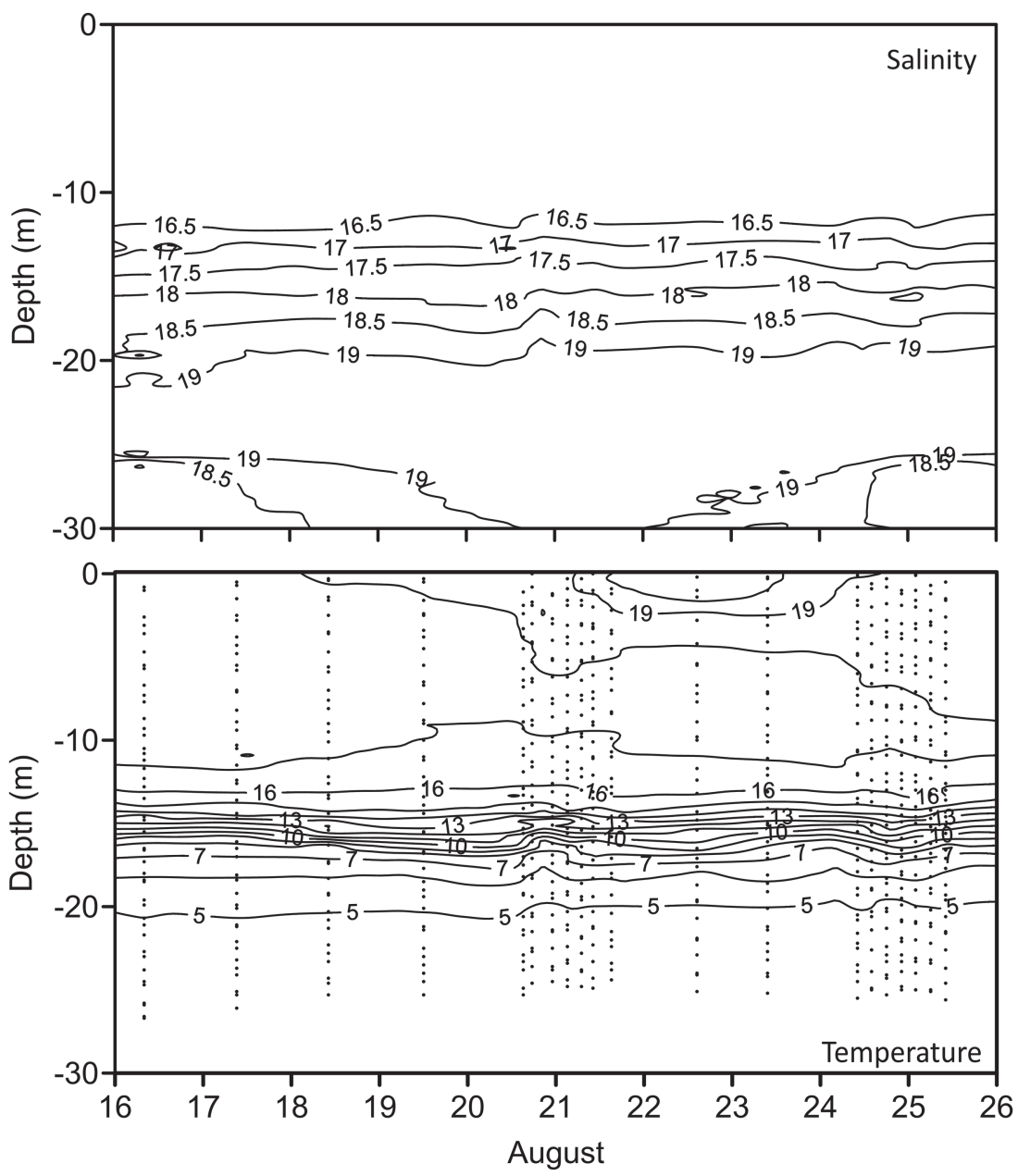

Fig. 3. Isopleths of salinity and temperature $\left({ }^{\circ} \mathrm{C}\right)$, in the inner part of Mariager Fjord.

the rotifer Synchaeta sp. were more $\mathrm{pH}$ resistant. All of these species increased in numbers during the incubation at $\mathrm{pH} 8$, significantly for Strombidium spp. $(P=0.022), L$. oviformis $(P=0.0002)$ and Synchaeta sp. $(P=0.002)$, while there were significant declines in abundance at higher $\mathrm{pH}$. Declines in population numbers were observed at $\mathrm{pH}$ 8.5 for Strombidium spp., 9.0 for $L$. oviformis and 9.5 for $O$. rotunda and Synchaeta sp. Hence, apart from M. rubrum and Strombidium spp. a pH tolerance to $\mathrm{pH} 9$ was observed; evidently higher $\mathrm{pH}$ levels led to declines in populations numbers.

\section{Bottle experiments}

The 24-h bottle experiments were conducted to monitor possible effects of Mariager Fjord relevant elevated $\mathrm{pH}$ on three groups of meroplankton. These organisms were collected individually and incubated for $24 \mathrm{~h}$ in the $\mathrm{pH}$ range. Bivalvia larvae showed a gradual response, starting to decline already at $\mathrm{pH} 8.5$ reaching almost zero survival at $\mathrm{pH} \geq 9.5$, but lack of replicates prevent statistical analysis. The polychaeta larvae and cirripedia nauplii survived pH levels up to 10, above which they significantly declined or were all dead (Fig. 9).

Copepod survival was unaffected up to $\mathrm{pH}$ 10, followed by a drastic mortality at $\mathrm{pH} 10.5$. They exhibited equal egg production at all $\mathrm{pH}$ treatments up to $\mathrm{pH} 9.5$, and no significant effect on egg hatching success was observed (Fig. 9).

\section{DISGUSSION}

The ocean acidification phenomenon caused by increasing anthropogenic $\mathrm{CO}_{2}$ loading is expected to have its greatest impact in the open ocean (Hofmann et al., 2011; 


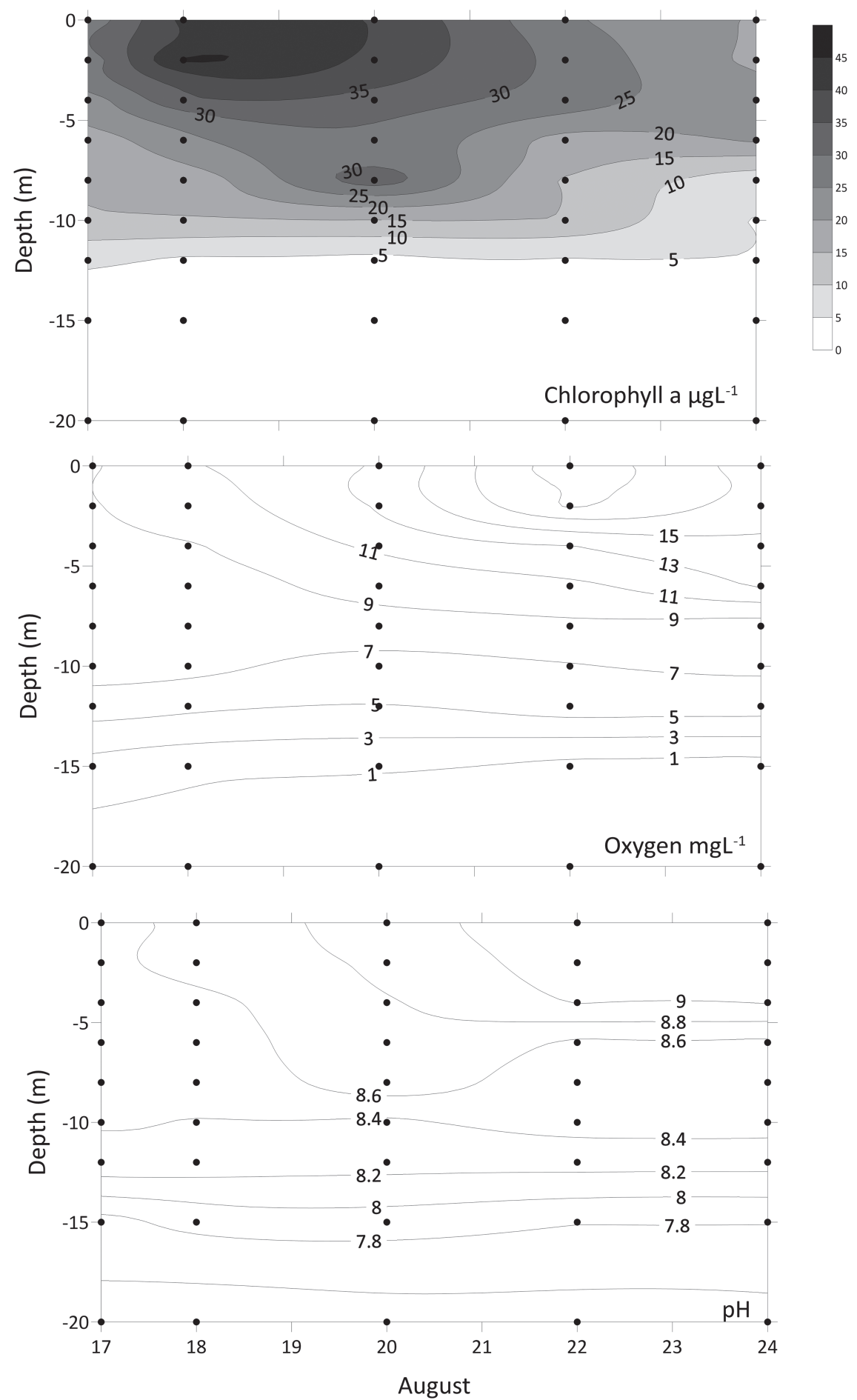

Fig. 4. (Isopleths of chlorophyll $\left.\mu \mathrm{g} \operatorname{chl} a \mathrm{~L}^{-1}\right)$ as proxy for phytoplankton biomass, oxygen concentration $\left(\mathrm{mg} \mathrm{L}^{-1}\right)$ and $\mathrm{pH}$ in the inner part of Mariager Fjord.

Duarte et al., 2013). However, eutrophic estuaries in e.g. Denmark and the UK are described to be prone to significant $\mathrm{pH}$ changes during summer (Howland et al.,
2000; Carstensen et al., 2018) and coastal phytoplankton may be negatively affected by elevated $\mathrm{pH}$ (e.g. Hinga, 2002; Hansen, 2002; Hansen et al., 2007). 

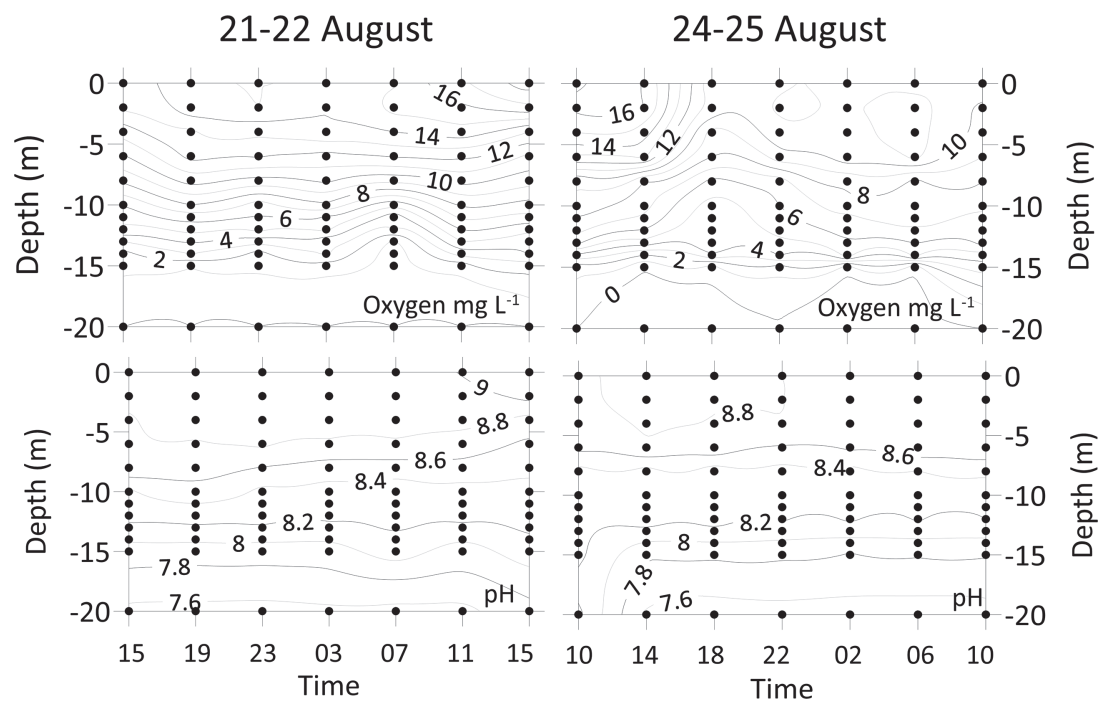

Fig. 5. Diurnal campaigns showing fluctuations of oxygen $\left(\mathrm{mg} \mathrm{L}^{-1}\right)$ in the upper panels and $\mathrm{pH}$ in the lower panels in the inner part of Mariager Fjord.

The critical environmental parameter for zooplankton in the model system here, Mariager Fjord, is the unusually high $\mathrm{pH}$ in surface waters during the productive season. Since hardly any zooplankton resides below the pycnocline, the zone above the pycnocline with surplus of food particles, elevated $\mathrm{pH}$ and negligible predation was our primary focus. To our knowledge, this study is the first to compare in situ observations of elevated $\mathrm{pH}$ with spatial and temporal distribution to $\mathrm{pH}$ challenge experiments of zooplankton, spanning from protistan to metazoan plankton. The ambition of the present study was to test the hypothesis that the zooplankton distribution pattern can be explained by the alkalinity of the water and the corresponding sensitivity of the organisms to elevated $\mathrm{pH}$ levels. An abundant literature exists on organismal responses to anthropogenic low $\mathrm{pH}$ (e.g. Duarte et al., 2013), but there is a clear lack of data for the common and natural conditions of high $\mathrm{pH}$.

The hydrography during the sampling campaign revealed a very stable scenario with hardly any changes in salinity in the water column. According to Hansen et al. (2002) the water change in the inner estuary is limited. This narrow fjord receives land runoff and regular intrusions of water from the open Kattegat. The latter can be identified by salt balance calculations and by changes in phytoplankton composition. Major water intrusion and freshwater runoff to Mariager inner fjord in 1998 took place in May and minor intrusions in JuneJuly. Hence, there are reasons to believe that negligible water intrusions took place during our campaign in late August 2005. Moreover, it was a dry summer with hardly any wind and where limited freshwater runoff took place, why we strongly believe we sampled in the same water mass during the present study.

Elevated $\mathrm{pH}$ in estuarine systems is often associated with high photosynthetic activity, which is indeed characteristic for Mariager Fjord. It is considered one of the most productive estuaries in the world and the primary production reaches on an annual basis $\sim 1000 \mathrm{~g} \mathrm{C} \mathrm{m}^{-2}$ in the inner part of the estuary (Conley et al. 2000; Olesen 2001). For comparison, >30 Danish estuaries and the Gullmar Fjord on the nearby Swedish west coast has an annual production ranging from $200-350 \mathrm{~g} \mathrm{C} \mathrm{m}^{-2}$ (Conley et al., 2000; Tiselius et al., 2016). The massive primary production cause oxygen depletion below the pycnocline (Olesen 2001) as verified here. Mariager Fjord hosts a high biomass of benthic suspension feeding animals but metazoan plankton populations are in general small (Tiselius et al., 2008).

The substantial primary production generates a high $\mathrm{pH}$ due to uptake of inorganic carbon by the phytoplankton. The inorganic carbon-drain exceeds the delivery rate from the bicarbonate system, which challenges the estuarine buffer system driving the $\mathrm{pH}$ upwards (Chen and Durbin, 1994). The elevated $\mathrm{pH}$ has been suggested to structure the phytoplankton community during the productive season (April-October) in Mariager Fjord leaving only a few species able to tolerate the $\mathrm{pH}$ often reaching well above 9 and even 9.75 during daytime (Hansen, 2002). The phytoplankton community is often totally dominated by the chainforming diatom S. marinoi (Hansen etal., 2002) as described for the present campaign by Tiselius et al. (2008) or by the phototrophic dinoflagellates $H$. triquetra and 

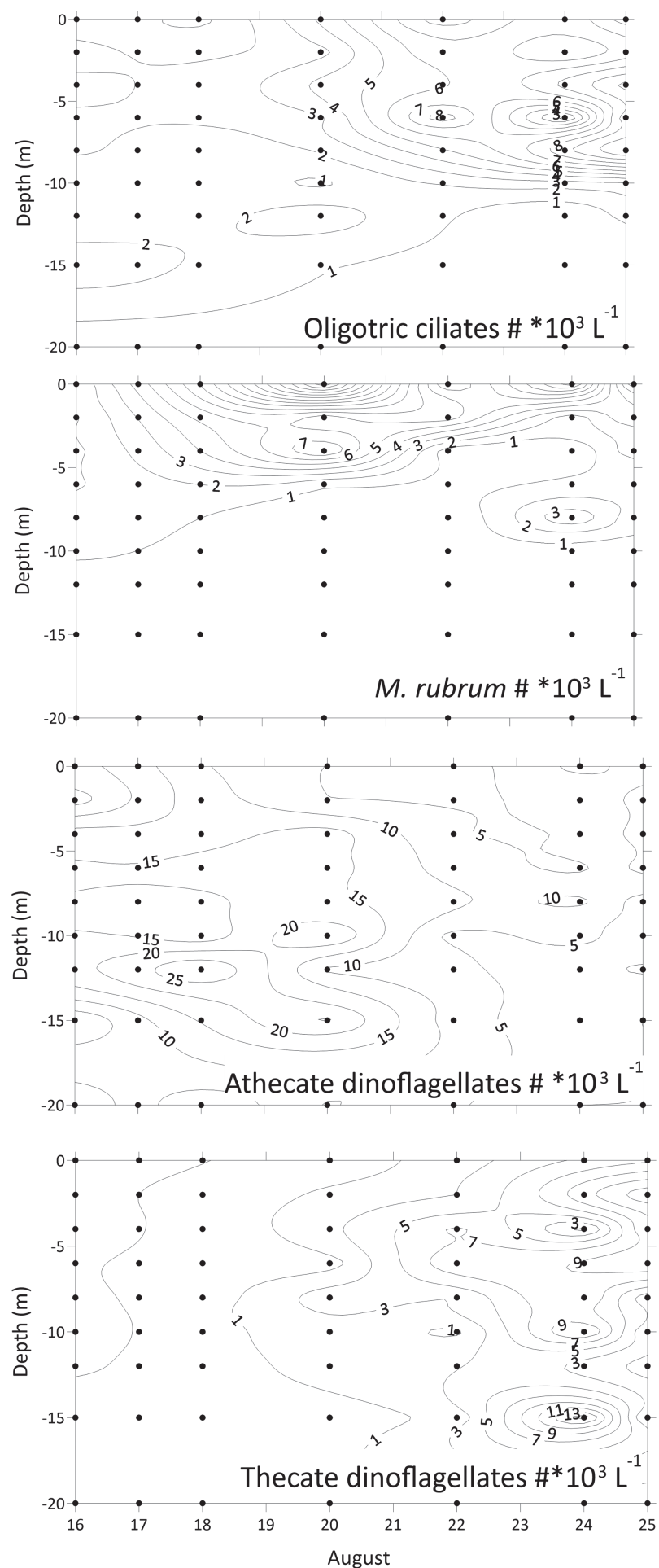

Fig. 6. Isopleths of the distribution of the major taxa of protistan grazers in the inner part of Mariager Fjord (abundance in individuals $\mathrm{L}^{-1}$ ).

Prorocentrum minimum (Hansen et al., 2002). During the period, late autumn to early spring, the phytoplankton community is more diverse (Olesen, 2001). Some of the dinoflagellates and especially the colonial diatoms are too large prey items for many of the pelagic suspension feeders. Polychaete (spionid) metatrochophora larvae and 

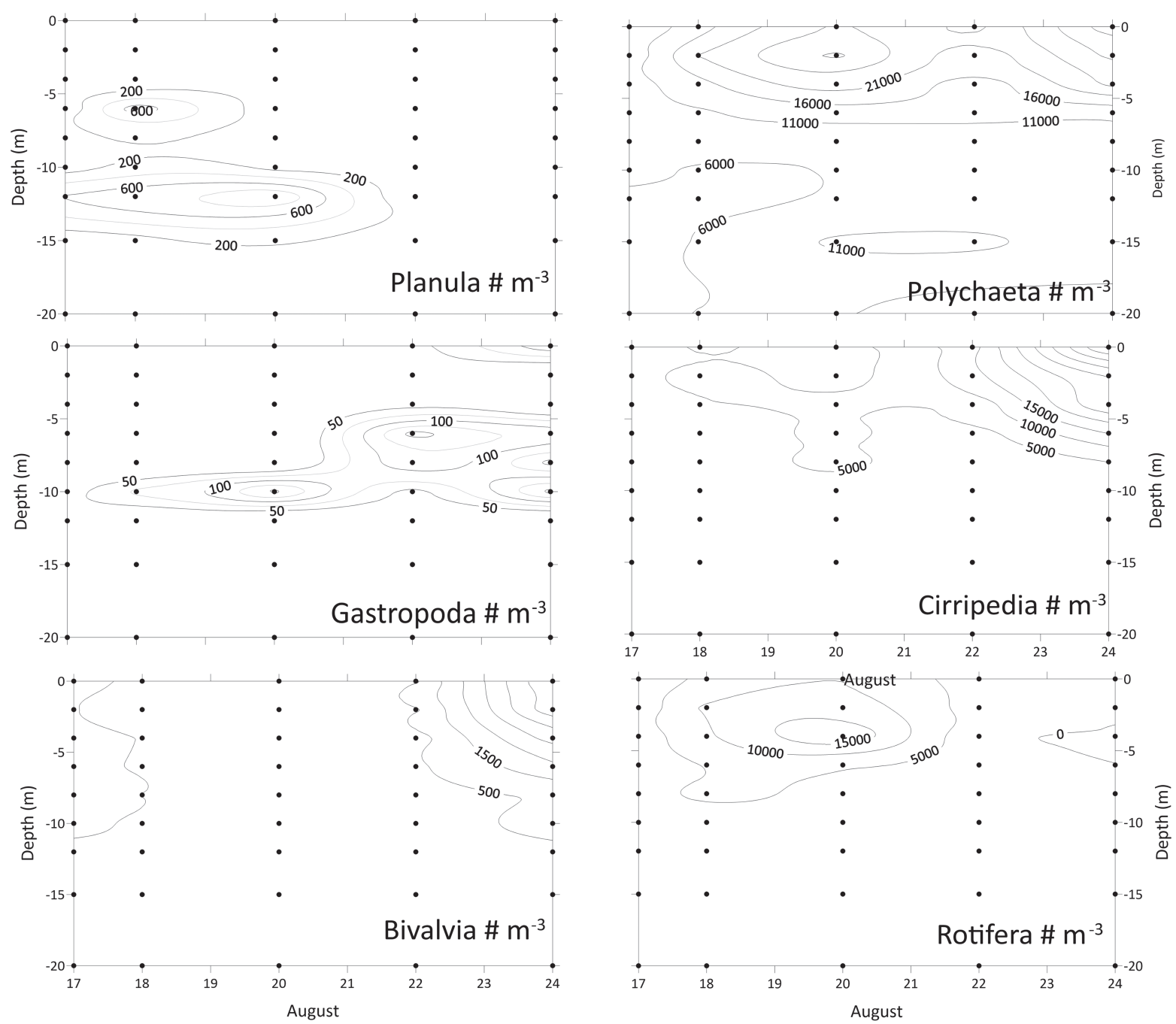

Fig. 7. Isopleths of the predominant meroplankton and rotifers distribution in the inner part of Mariager Fjord (abundance in individuals $\mathrm{m}^{-3}$ ).

the advanced copepodite stages of the copepod A. tonsa can feed on a large spectrum of food particles including the ones from the present system (Berggreen et al., 1988; Hansen, 1999). However, gastropod and bivalve veligers cannot feed on the larger particles (Hansen, 1991; Petersen et al., 2002) that even obstruct their feeding and swimming (Hansen et al., 1991). Cirriped nauplii as well as the rotifer Brachionus plicatilis, which can be used as a proxy for pelagic rotifers in general, prefer small-sized algae (28 um) (e.g. Tackx et al., 1990; Hansen et al., 1997). Hence, even though the pelagic grazers physiologically might tolerate elevated $\mathrm{pH}$ they could be indirectly challenged by facing functional lack of food and even starvation due to a mismatch between their retention spectrum and the sizes of the ambient prey available (e.g. Petersen et al., 2002).
Since the extent and persistence of elevated $\mathrm{pH}$, as observed in the inner Mariager Fjord during the productive season, has been suggested to structure the phytoplankton community (Hansen, 2002), it is likewise (directly or indirectly) possibly structuring various components of the zooplankton community. However, the literature on the effects of elevated $\mathrm{pH}$ on the different protistan and metazoan grazers is still quite limited (Pedersen and Hansen, 2003a, 2003b; Hansen et al., 2017).

The abundance and biomass of protistan grazers were quite low during this field campaign, taking the high biomass of primary producers into consideration (see for comparison Zervoudaki et al., 2009 for open water Kattegat). This indicates that some of the protistan grazers are limited in their production rates, which is also what we 

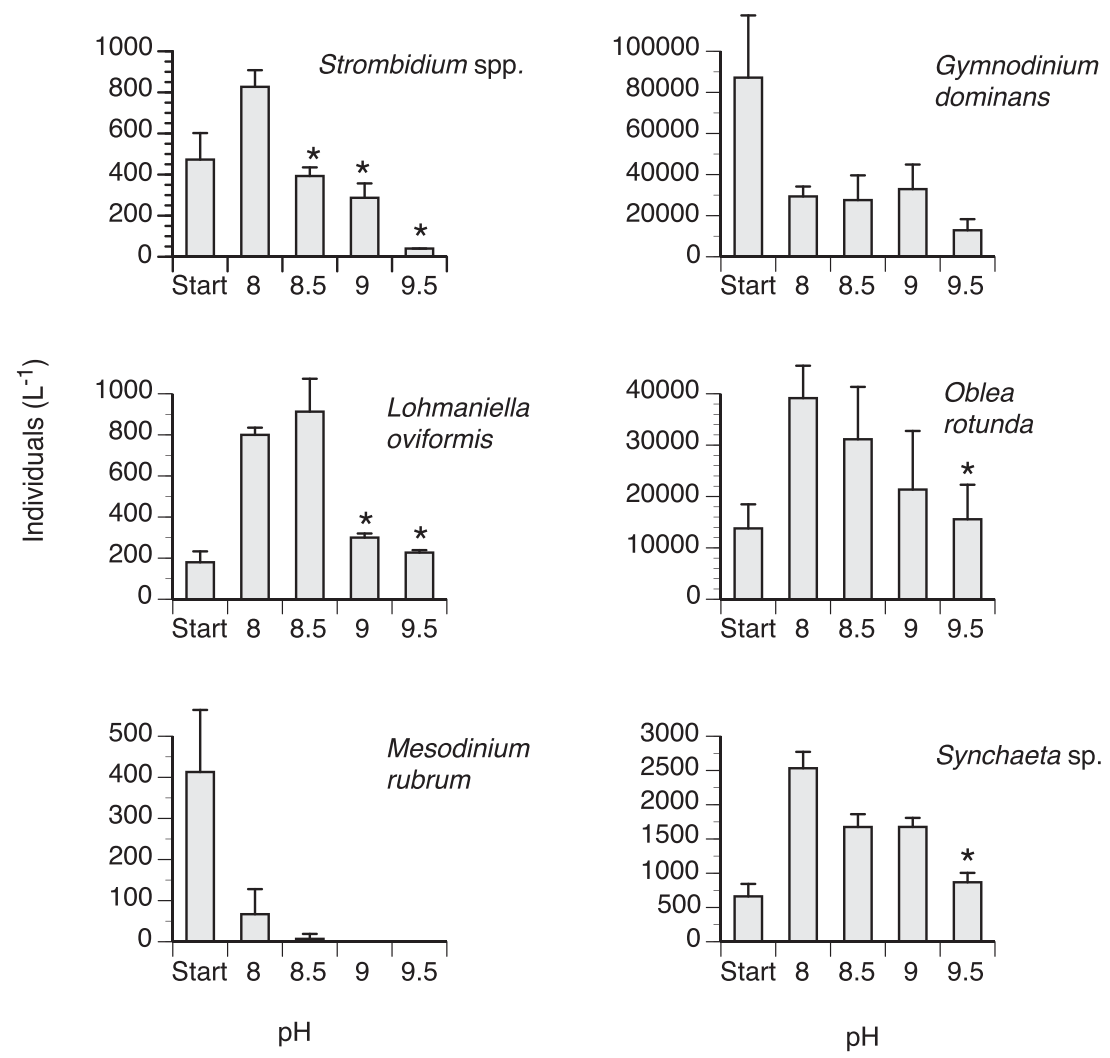

Fig. 8. Results of $30 \mathrm{~L}$ microcosm $\mathrm{pH}$ challenge experiment on the growth of heterotrophic dinoflagellates (Gyrodinium dominans and $O$. rotunda), heterotrophic ciliates (L. oviformis and Strombidium spp,), mixotrophic ciliates (M. rubrum) and the rotifer Synchaeta sp. $(n=3$, mean \pm SD).

found during our incubation experiments. It is, however, notice worthy that initial abundance in our challenge experiments was lower than in situ presumably due to initial screening and some container effects in a few cases (i.e. the protistan grazers $M$. rubrum and G. dominans). This presumably did not influence the recorded growth rates. Elsewhere it has been observed in laboratory studies on $M$. rubrum, which have positive growth rates above $\mathrm{pH}$ 8.5, that this species cannot grow at $\mathrm{pH}$ exceeding 8.7-8.8 (Hansen and Fenchel, 2006; Smith and Hansen, 2007). In addition, our experimental data indicate that some succession of species of protistan grazers will occur during such high $\mathrm{pH}$ events. Similar observations have been made in incubations of eutrophic coastal brackish water field populations (Øresund; part of the Baltic Sea) as well as observed in natural environments in hypertrophic enclosed brackish waters experiencing $\mathrm{pH}$ of up to 9.3 (Chomérat et al., 2004). This pH tolerance supports our in situ observations of athecate and thecate dinoflagellates presence in the entire water column. Some initially abundant species were indeed very sensitive to $\mathrm{pH}$ above 9; this we observed both in the natural environment and in the $\mathrm{pH}$ incubation experiments. The tolerance to high $\mathrm{pH}$ among protistan grazers is, consequently, species-specific, and the upper $\mathrm{pH}$ growth limits for heterotrophic dinoflagellates and ciliates have been found to vary between 8.4 and 10.2 (see Pedersen et al., 2003b). New populations of protistan grazers will of course be supplied by water intrusions from the Kattegat area during westerly storms. This means that when $\mathrm{pH}$ in the inner estuary start to decline during autumn, organisms will be supplied to the inner estuary from the Kattegat, resetting the community structure every year.

Meroplankton was present with few groups. The predominant taxa was gastropods, polychaetes and cirriped nauplii (Figs 2 and 7). In addition, a few bivalve larvae were present but with such low abundance, not enough to conduct $\mathrm{pH}$ challenge experiments, which is why we recruited organisms from a neighboring estuary. We did no exposure experiments with gastropod larvae, but they reside in the depth strata 5-10 $\mathrm{m}$ where the $\mathrm{pH}$ never reached higher than 8.4-8.8. However, we challenged polychaete larvae and cirriped larvae, both residing above $10 \mathrm{~m}$ depth and some polychaete larvae were distributed in the entire water column. They could 

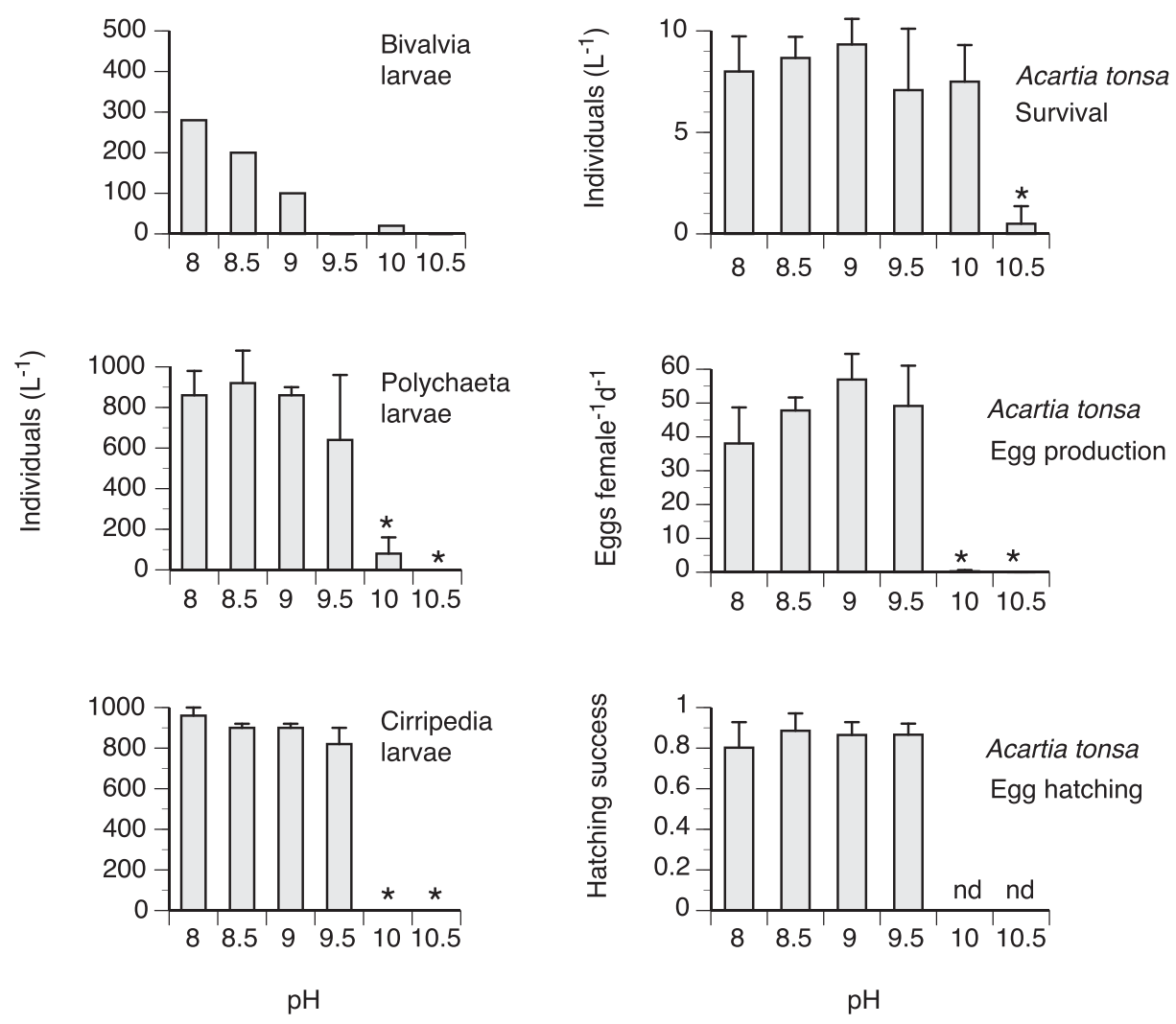

Fig. 9. Results of 50-ml bottle $\mathrm{pH}$ challenge experiments with meroplankton and in 500-mL bottle experiments for the only copepod species, which are predominant in the inner part of Mariager Fjord. $(n=3$, mean \pm SD). Treatments marked with asterisks are statistically different from $\mathrm{pH} 8$.

all tolerate very high $\mathrm{pH}$ and apparently low oxygen and as such seem well adapted to the situation in the inner estuary. Bivalve larvae are possibly quite vulnerable to elevated $\mathrm{pH}$ based on our tentative experiment, and additionally not well adapted to the prevalent food particle regime. They were only present in the beginning and the end of our campaign; however, they nevertheless resided in the surface water and were exposed to $\mathrm{pH}>9$. This position in the water column is non-viable for the larvae over an entire pelagic phase of 3-4 weeks, when coinciding with elevated $\mathrm{pH}$ during summer. Hence, either local mussels provide the necessary quantum of propagules at other times of the year where $\mathrm{pH}$ is lower or the larvae stems from populations inhabiting the outer part of the estuary. This input of propagules is likely supplying the inner part with blue mussel recruits and other larvae from benthic invertebrates (see Hansen et al., 2002).

Moreover, it is well documented that such an extreme $\mathrm{pH}$ elevation (in combination with anoxia) as documented in the present study, kills a number of copepod species (Pedersen and Hansen, 2003a; Hansen et al., 2017). Hence, practically only one species is present in the inner section of Mariager Fjord (Tiselius et al., 2008) which species assemblage is significantly reduced compared to open water Kattegat assemblages (Zervoudaki et al., 2009). This is most likely an indirect effect, possibly due to lack of ability to cope with the available phytoplankton food by the juvenile stages of $A$. tonsa (Berggreen et al., 1988). In other words, it is not necessarily a direct effect since it recently has been documented that when compared to $A$. tonsa some of the other copepod species present in the estuary at low numbers are just asor even more tolerant to elevated $\mathrm{pH}$ (Hansen et al., 2017). One could speculate that those copepod species cannot cope with chain-forming diatoms, but that remains to be verified. The $A$. tonsa spatial distribution is life-stage dependent, but at a species level, they inhabit the entire water column (see Tiselius et al., 2008 for stage specific distribution). Their response to hypoxia was well studied by Marcus et al. (2004) showing although egg production and population growth is reduced at oxygen concentrations of 0.7 and 1.5 $\mathrm{mg} \mathrm{L^{-1 }}$ just the lowest oxygen concentration caused significant death. The presence of $A$. tonsa in the entire 
water column is supported by the present laboratory observation of tolerance to $\mathrm{pH} \geq 9.5$ with good survival, reproduction and egg hatching. The same tolerance to elevated $\mathrm{pH}$ is also demonstrated by wild as well as long-term culture specimens of the same species originating from Øresund, Denmark where they are not adapted to elevated $\mathrm{pH}$ (Hansen et al., 2017). Why are they not abundant then, but only present by $5-$ $10 \%$ as compared to open water habitats just outside the estuary? Tiselius et al. (2008) proposed a significant recruitment loss due to the bulk part of their eggs sinking to the anoxic bottom layer preventing hatching combined with eggs and juvenile stages being grazed by the band of filtrating blue mussels situated at 5-10 $\mathrm{m}$ depth in the inner section of the estuary (Lomstein, 1999; Tiselius et al., 2008). Moreover, Hansen et al. (2017) reported that even though $A$. tonsa eggs should hatch at $\mathrm{pH} 9.5$ the nauplii die at elevated $\mathrm{pH}$ when leaving their protective embryonic membrane in the eggs.

\section{GONGLUSION}

We demonstrated that there are a few but persistent protistan and metazooplankton organisms robust enough to combat the hostile environmental conditions of the inner part of Mariager Fjord, with anoxic bottom water and elevated $\mathrm{pH}$ above the pycnocline. Mariager Fjord has a long and slender shallow-water outer section in open connection toward Kattegat. Both these habitats are typically well oxygenated, with moderate $\mathrm{pH}$ fluctuations and a species-rich benthic community hosting a healthy and diverse invertebrate fauna, which presumably supply the inner estuary with propagules. We suggest that these propagules are advected to the inner estuary, but to a large extend are eliminated by environmental challenges, leaving only the 'real opportunistic survivors' to inhabit the high-pH inner part of Mariager Fjord. Moreover, we suggest that our observations are not only restricted to the present ecosystem but of more general character for hypereutrophic estuaries.

\section{ACKNOWLEDGEMENTS}

We thank lab technician Jens Erik Nybo Larsen for invaluable help during the field campaign.

\section{FUNDING}

Villum Foundation project AMPHICOP (no. 1089 to B.W.H.) and National Research Council (project no. 21-03-0449 to P.J.H.).

\section{REFERENGES}

Berge, T., Daugbjerg, N., Andersen, B. B. and Hansen, P.J. (2010) Effect of lowered $\mathrm{pH}$ on marine phytoplankton growth rates. Mar. Ecol. Prog. Ser., 416, 79-91.

Berggreen, U. C., Hansen, B. and Kiørboe, T. (1988) Food size spectra, ingestion and growth of the copepod Acartia tonsa during development: implication for determination for copepod production. Mar. Biol., 99, 341-352.

Carstensen, J., Chierici, M., Gustavsson, B. G. and Gustavsson, E. (2018) Long-term and seasonal trends in estuarine and coastal carbonate systems. Global Biogeochem. Cycles, 32, 497-513.

Chen, C. Y. and Durbin, E. G. (1994) Effects of pH on the growth and carbon uptake of marine phytoplankton. Mar. Ecol. Prog. Ser., 109, 83-94.

Chomérat, N., Couté, A., Fayolle, S., Mascarell, G. and Cazaubon, A. (2004) Morphology and ecology of Oblea rotunda (Diplopsalidaceae, Dinophyceae) from a new habitat: a brackish and hypertrophic ecosystem, the E'tang de Bolmon (south of France). Eur. F. Phycol., 39, 317-326.

Conley, D. J., Kaas, H., Møhlenberg, F., Rasmussen, B. and Windolf, J. (2000) Characteristics of Danish estuaries. Estuaries, 23, 820-837.

Droop, M. R. (1959) A note on some physical conditions for cultivating Oxyrrhis marina. F. Mar. Biol. Assoc. U. K., 38, 599-604.

Duarte, C.M., Hendriks, I.E., Moore, T.S., Olsen, Y.S., Steckbauer, A., Ramajo, L., Carstensen, J., Trotter, J.A. et al. (2013) Is ocean acidification an open-ocean syndrome? Understanding anthropogenic impacts on seawater pH. Estuaries and Coasts, 36, 221-236.

Edler, L. (1979) Recommendations for marine biological studies in the Baltic Sea. Phytoplankton and chlorophyll. Baltic Mar. Biol. Publ., 5, $1-38$.

Fallesen, G., Andersen, F. and Larsen, B. (2000) Life, death and revival of the hypertrophic Mariager Fjord. Denmark. F. Mar. Syst., 25, 313-321.

Fenchel, T., Bernard, C., Esteban, G., Finlay, B. J., Hansen, P. J. and Iversen, N. (1995) Microbial diversity and activity in a Danish fjord with anoxic deep water. Ophelia, 43, 45-100.

Fenchel, T. and Hansen, P. J. (2006) Motile behaviour of the bloomforming ciliate Mesodinium rubrum. Mar. Biol. Res., 2, 33-40.

Fotel, F. L., Jensen, N. J., Wittrup, L. and Hansen, B. W. (1999) In situ and laboratory growth by a population of blue mussel larvae (Mytilus edulis L.) from a Danish embayment, Knebel Vig. f. Exp. Mar. Biol. Ecol., 233, 213-230.

Hansen, B. (1991) Feeding behaviour in larvae of the opisthobranch Philine aperta (L.) II. Food size spectra and particle selectivity in relation to larval behaviour and morphology of the velar structures. Mar. Biol., 111, 263-270.

Hansen, B. (1999) Cohort growth rate of planktotrophic polychaete larvae - are they food limited? Mar. Ecol. Prog. Ser., 178, 109-119.

Hansen, B., Hansen, P. J. and Nielsen, T. G. (1991) Effects of large nongrazable particles on clearance and swimming behavior of zooplankton. F. Exp. Mar. Biol. Ecol., 152, 257-269.

Hansen, B. and Ockelmann, K. W. (1991) Feeding behaviour in larvae of the opisthobranch Philine aperta (L.) I. Growth and functional response at different developmental stages. Mar. Biol., 111, 255-261.

Hansen, B., Wernberg-Møller, T. and Wittrup, L. (1997) Particle grazing efficiency and specific growth efficiency of the rotifer Brachionus plicatilis (Muller). F. Exp. Mar. Biol. Ecol., 215, 217-233. 
Hansen, B. W., Stenalt, E., Petersen, J. K. and Ellegaard, C. (2002) Invertebrate re-colonisation in Mariager Fjord (Denmark) after a severe hypoxia. I. Zooplankton and settlement. Ophelia, 56, 197-213.

Hansen, B. W., Hansen, P. J., Nielsen, T. G. and Jepsen, P. M. (2017) Effects of elevated $\mathrm{pH}$ on marine copepods in mass cultivation systems - practical implications. F. Plankton Res., 39, 984-993.

Hansen, P. J. (2002) Effect of high $\mathrm{pH}$ on the growth and survival of marine phytoplankton: implications for species succession. Aquat. Microb. Ecol., 28, 279-288.

Hansen, P. J. and Fenchel, T. (2006) The bloom-forming ciliate Mesodinium rubrum harbours a single permanent endosymbiont. Mar. Biol. Res., 2, 169-177.

Hansen, P. J., Lundholm, N. and Rost, B. (2007) Growth limitation in marine red-tide dinoflagellates: effects of $\mathrm{pH}$ versus inorganic carbon availability. Mar. Ecol. Prog. Ser, 334, 63-71.

Hinga, K. R. (2002) Effects of $\mathrm{pH}$ on coastal marine phytoplankton. Mar. Ecol. Prog. Ser., 238, 281-300.

Hofmann, G.E., Smith, J.E., Johnson, K.S., Send, U., Levin, L.A., Micheli, F., Paytan, A., Price, N.N. et al. (2011) High-frequency dynamics of ocean $\mathrm{pH}$ : a multi-ecosystem comparison. PLOS ONE 6: e28983. doi:10.1371/journal.pone.0028983.

Howland, R. J. M., Tappin, A. D., Uncles, R. J., Plummer, D. H. and Bloomer, N. J. (2000) Distributions and seasonal variability of $\mathrm{pH}$ and alkalinity in the tweed estuary, UK. Sci. Total Environ., 251/252, 125-138.

Jespersen, A. M. and Christoffersen, K. (1987) Measurements of chlorophyll-a from phytoplankton using ethanol as extraction solvent. Arch. Hydrobiol., 109, 445-454.

Labasque, T., Chaumeryb, C., Aminotc, A. and Kergoata, G. (2004) Spectrophotometric Winkler determination of dissolved oxygen: reexamination of critical factors and reliability. Mar. Chem., 88, 53-60.

Lessard, E. J. (1991) The trophic role of heterotrophic dinoflagellates in diverse marine environments. Mar. Microb. Food Webs, 5, 49-58.

Lomstein, B. A. (ed.) (1999) Havmiljøet ved årtusindskiftet (Marine Environments into the Millenium). Olsen \& Olsen, Fredensborg. 176 00. [in Danish]. ISBN 87-85215-33-3.

Marcus, N. H., Richmond, G., Sedlacek, G., Miller, G. A. and Oppert, C. (2004) Impact of hypoxia on the survival, egg production and population dynamics of Acartia tonsa Dana. F. Exp. Mar. Biol. Ecol., 301, $111-128$.

Nielsen, L. T., Jakobsen, H. H. and Hansen, P. J. (2010) High resilience of two coastal plankton communities to twenty-first century seawater acidification: evidence from microcosm studies. Mar. Biol. Res., 6, $542-555$.
Olesen, M. (2001) Sedimentation in Mariager Fjord, Denmark: the impact of sinking velocity on system productivity. Ophelia, 55, $11-26$.

Pedersen, M. F. and Hansen, P. J. (2003a) Effects of high pH on a natural marine planktonic community. Mar. Ecol. Prog. Ser., 260, 19-31.

Pedersen, M. F. and Hansen, P. J. (2003b) Effects of high pH on the growth and survival of six marine heterotrophic protists. Mar. Ecol. Prog. Ser., 260, 33-41.

Petersen, J. K., Stenalt, E. and Hansen, B. W. (2002) Invertebrate recolonisation in Mariager Fjord (Denmark) after a severe hypoxia. II. Blue mussels (Mytilus edulis L.). Ophelia, 56, 215-226.

Ringwood, A. H. and Keppler, C. J. (2002) Water quality variation and clam growth: is $\mathrm{pH}$ really a non-issue in estuaries? Estuaries, 25, 901-907.

Rost, B., Zondervan, I. and Wolf-Gladrow, D. (2008) Sensitivity of phytoplankton to future changes in ocean carbonate chemistry: current knowledge, contradictions and research directions. Mar. Ecol. Prog. Ser., 373, 227-237.

Smith, M. and Hansen, P. J. (2007) Interaction between M. rubrum and its prey: importance of irradiance, prey concentration, and $\mathrm{pH}$. Mar. Ecol. Prog. Ser., 338, 61-70.

Tackx, M. L. M., Bakker, C. and Van Rijswijk, P. (1990) Zooplankton grazing pressure in the Oosterschelde (The Netherlands). Neth. F. Sea. Res., 25, 405-415.

Talling, J. F. (1976) The depletion of carbon dioxide from lake water by phytoplankton. F. Ecol., 64, 79-121.

Tiselius, P., Borg, C. M. A., Hansen, B. W., Hansen, P. J., Nielsen, T. G. and Vismann, B. (2008) High reproduction, but low biomassmortality estimates of the copepod Acartia tonsa during a Skeletonema costatum bloom. Aquatic Biol., 2, 93-103.

Tiselius, P., Belgrano, A., Andersson, L. and Lindahl, O. (2016) Primary productivity in a coastal ecosystem: a trophic perspective on a longterm time series. F. Plankton Res., 38, 1092-1102.

Ütermöhl, H. (1958) Zur Vervollkommung der quantitativen Phytoplankton-Metodik. Mitt. Int. Ver. Theor. Angew. Limnol., 9, 39 .

Zervoudaki, S., Nielsen, T. G. and Carstensen, J. (2009) Seasonal succession and composition of the zooplankton community along an eutrophication and salinity gradient exemplified by Danish waters. 7. Plankton Res., 12, 1475-1492.

Yentsch, C. S. and Menzel, D. W. (1963) A method for the determination of phytoplankton chlorophyll and phaeophytin by fluorescence. Deep Sea Res., 10, 221-231. 